\title{
Transformation of the Historical Street Settlements and Structures of the city of Jelgava / Mitau in the Post-War Years
}

\author{
Aija Ziemel̦niece, Latvia University of Life Sciences and Technologies, Latvia
}

\begin{abstract}
Jelgava, as the former capital of the Duchy of Kurzeme and the times of the province, was vividly characterized by a strong German environment, which made a financially strong contribution to the city's economic prosperity. The urban construction period of the city from the beginning of the $19^{\text {th }}$ century marks 4 distinct periods: wooden settlements and buildings until the first half of the $19^{\text {th }}$ century, masonry structures until 40s of the $2^{\text {th }}$ century; implementation of standardised projects (large reinforced concrete panel buildings) from the $50 \mathrm{~s}$ to the $80 \mathrm{~s}$ of the $20^{\text {th }}$ century; trends for free-planning construction in the shift of $20^{\text {th }} / 21^{\text {st }}$ centuries.

The aim of the research is to evaluate the transformation processes of Katolu and Pasta streets in Jelgava urban planning space within the last century. Research assignments: comparing the change in the height, scale and structure of the historical pre-war and post-war buildings of Pasta and Katolu streets; changes in dominants of the St. John's [Sv. Jäna] church; synthesis of preserved historical buildings in post-war settlement and construction.
\end{abstract}

Keywords: street re-planning, building dismantling, urban planning structure, urban planning space

\section{Introduction}

The rapid boom of masonry buildings in Jelgava at the turn of the 19th/20th century and its architectural and artistic values disappeared with the Russian military aviation air strikes on the city carried out in year 1944. After the bombing, only a few walls of undamaged tenement houses in the central part of the city stretched like separate giant fingers against the sky. These were located along Akademijas, Pasta, Katolu, Svetes, Uzvaras, Dobeles streets.

In the 1950s, next to the undamaged historic houses, new construction began with a different understanding of the urban scale, emphasizing the political power of the time. The gaps along the streets began to be filled by shops, but also by typical residential buildings, schools, hospitals, 2-storey office buildings. The post-war construction, which grew instead of the burned buildings, did not preserve either the historically determined street construction line, nor the height. The new buildings were moved away from the street, thus avoiding the existing stone foundations, which would create uneven structural setting (foundation/underlying layer compaction) of the buildings. Knowing the collapse of the economy after the war, it was easier to dismantle and remove the ruins, but to leave the foundations of giant granite blocks in the ground, levelling and covering them with black compost earth, and planting trees and bushes on the surface. In this way, the orderliness of the urban environment was restored cheaply and on a visually acceptable level, and the places of war-burned buildings were disguised. Planting materials were obtained at the forest edges, namely - lindens, chestnuts, oaks. Especially popular were fast-growing aspens, white alder and poplar, the branch of which quickly covered the plaster of the scarred buildings carved by the war. Before the war, the streets of the central part of Jelgava were made without tree plantations [9]. Some of the newly built buildings were built in the former courtyards, where construction had never existed.

The second solution in the post-war urban planning was to change the street beds, which were moved away from the foundations of the burned buildings at a flat angle, but the old cellars were filled with ruins. The newly created wedge-shaped areas were built as street driveways or pedestrian areas, or by adapting them to the lanes with planted greenery. The consequences of the irresponsible solutions of the post-war years still cause a headache for the city municipality, as the different base of the ground creates uneven sedimentation (compacting), cracks and debris. These factors are due to levelled ruins, filled-in cellars, non-removed stone foundations - like a giant donkiotic struggle with wartime breath. In the underground of the city, it still breathes and makes itself noticed.

The study uses a comparative method based on information from archive materials and the current situation in urban planning of the city of Jelgava. A comparison of the historical and modern building territories of two streets - Katolu and Pasta streets - has been carried out [11].

\section{Results and Discussion}

In the graphic image (Fig. 1), using the aerial photography of 1930s, buildings ar marked that have survived after the war on Katolu and Pasta streets. Both streets are located $130 \mathrm{~m}$ from each other, and until the 1950s ended at the former Valnu street, 


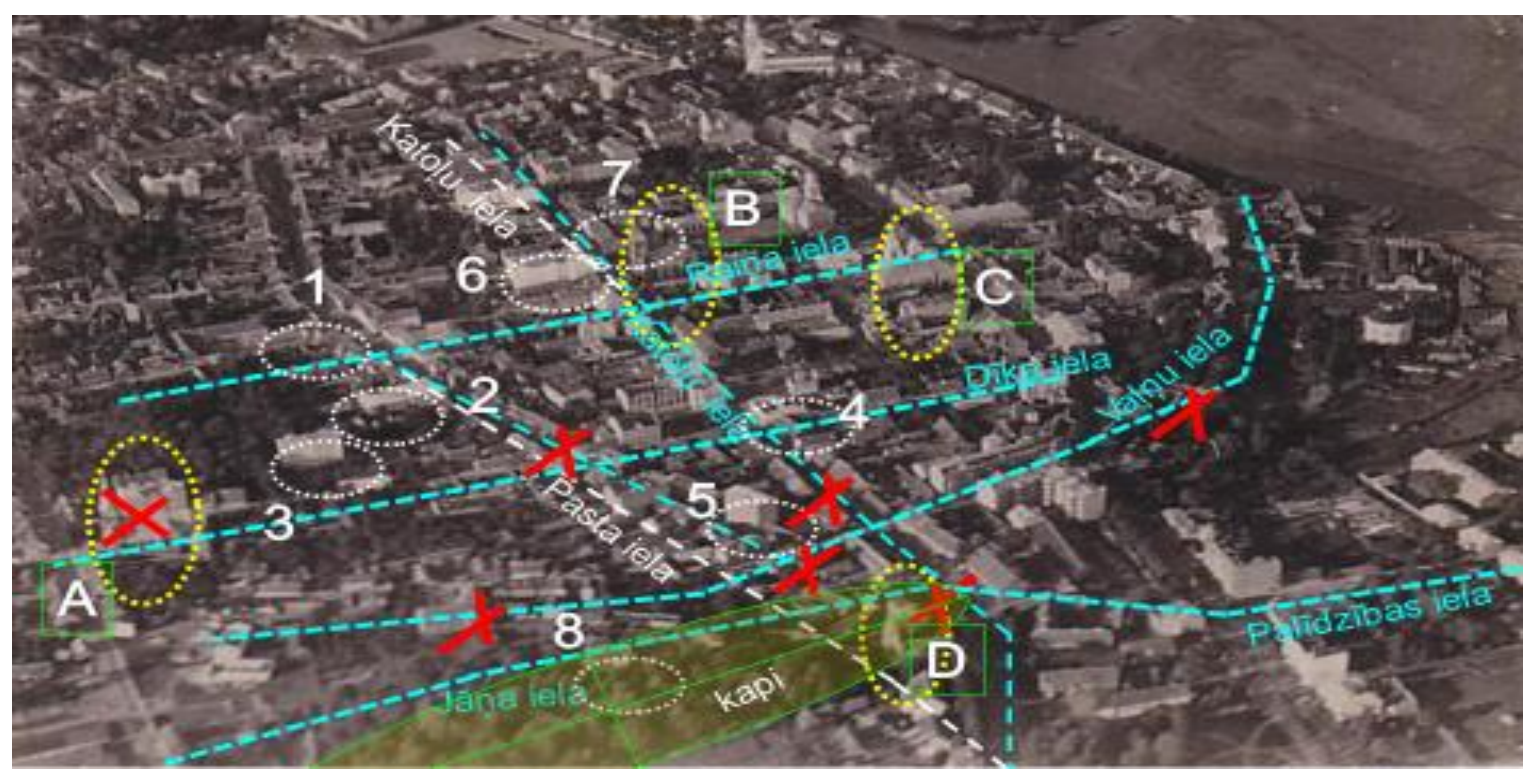

Fig. 1. Preserved historical buildings between Pasta-Katolu-Valnu streets [author's sketch on the map of the 1930s]. 1. Pasta street (Pasta street 14); 2. Russian Society Building (Pasta street 32); 3. Polyclinic building (S. Edzus street 10); 4. Tenement house, Katolu street 19; 5. Tenement house, Pasta street 53; 6. Tenement house, Katolu street 10; 7. Tenement house, Katolu street 9;

8. Graveyard Keeper's house, Jana iela 1. The scheme shows churches with an oval circle-from left: A-St. Nichola's

[Sv. Nikolaja]; B - St. Yuri's [Sv. Jura]; D-St. John's [Sv. Jān̨a]; C-St. Ann's and St. Simon's [Sv. Annas un Simaņa];

Red crosses mark sections of streets that have been destroyed after the war; the green ellipse marks the levelled historic St. John's [Sv. Jāna] Cemetery, which was destroyed in 1950s

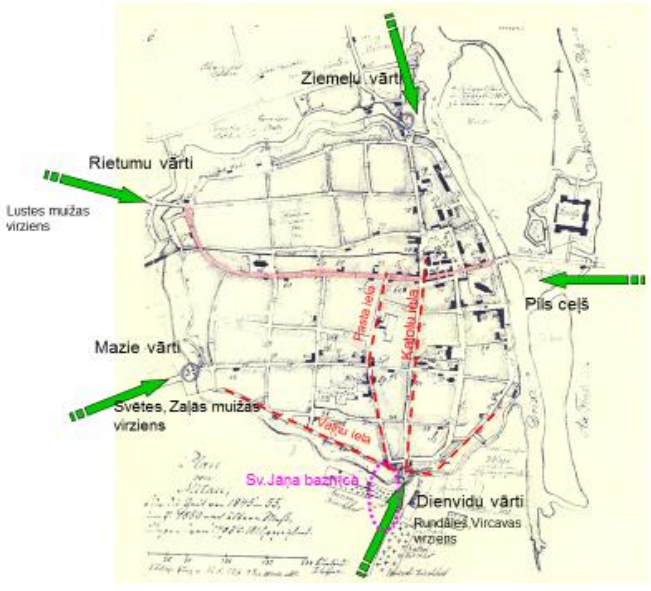

Fig. 2. Historic city gates before the demolition of the ramparts early $19^{\text {th }}$ century

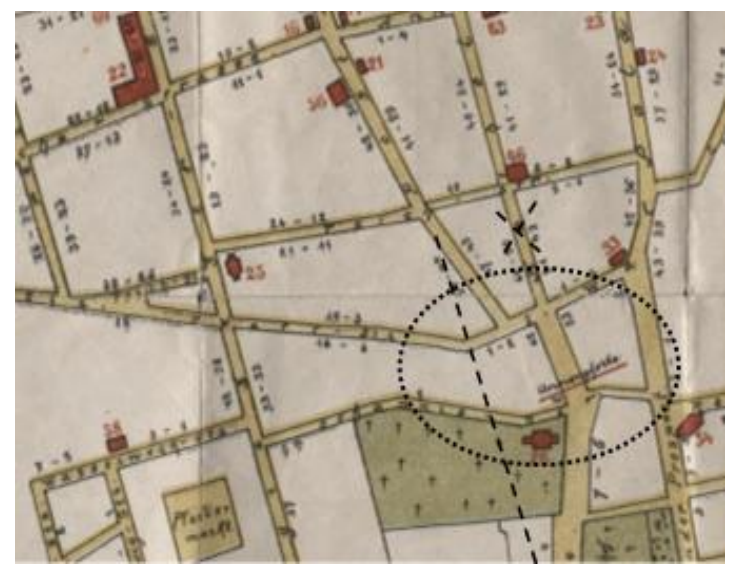

Fig. 3. Cross-point of the Katolu-Pasta-Valnu streets near the former Ann's [Annas] (Southern) ports. Nearby, St. John's

[Sv. Jāna] church with the graveyard is located.

Late $19^{\text {th }} /$ Early $20^{\text {th }}$ century Jelgava State Musuem [JVM] close to St. John's [Sv. Jāña] church, creating a dominant point for both streets in the southern part of the city, both visually and functionally. The continuation of Katolu street was still in the direction of Lithuania - Eleja and Augstkalne, in the period of 1950s. The structure of this town planning was dismantled in the post-war years. The study covers comparisons and transformation processes in the considered urban planning space.

\section{Katolu Street}

Katolu street is one of the city's streets, which has lost both its historic buildings and the street bed.

In the post-war years, when removing the ruins of buildings on Katolu street, the development of its construction can be divided into 3 periods:

- Northern part of the street (from Lielā to Raina street) - construction time during 50 s-60s of the 20th century;

- The middle section of the street - from Raina to S. Edzus (Dika) street, in the $60 \mathrm{~s}$ of the 20th century;

- Southern part of the street - from S. Edzus to Jana street, in the 1970s.

Its historical length until the 1950s was around $1200 \mathrm{~m}$. The street started at the old Market Square and reaches south towards Lithuania until the railway tracks [8]. The historical bed of Katolu street from the intersection of Raina Street to the old Market Square in the post-war years has acquired a wedge-shaped 9-degree bevel to form a departure from the old foundations of the buildings. The entire building of the street was demolished, so it was easy to build the new street. 


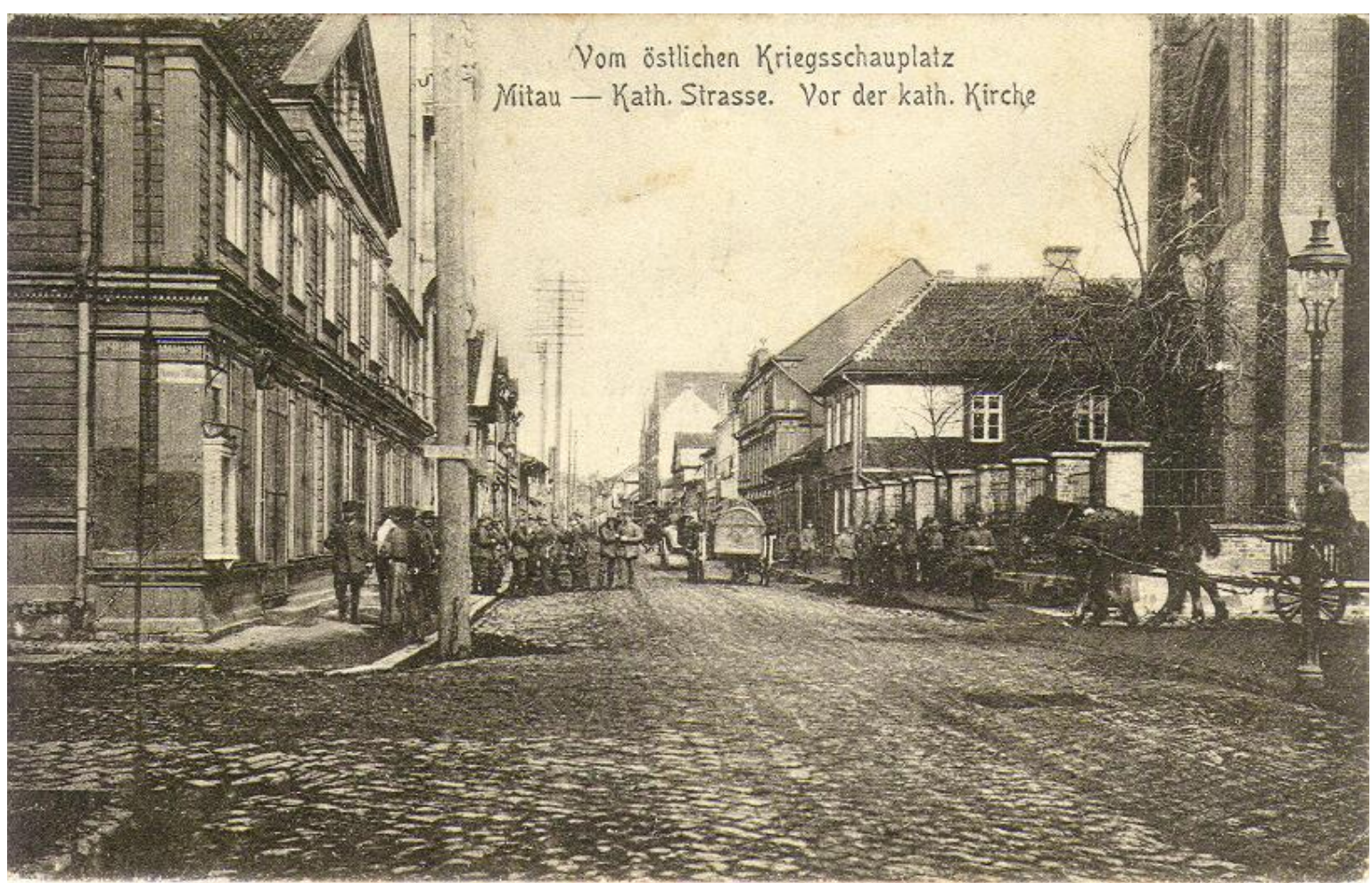

Fig. 4. Intersection of Katolu and Raina streets near St. Yuri's [Sv. Jura] church. Early $20^{\text {th }}$ century [JVM]

This includes the construction period of the socalled Stalin's residential block houses (Stalinkas), which was popular in late 1940s, when these were gradually phased out by the so-called Khrushchev's residential block houses (Khrushchevkas), the construction period of which were the 50 s to $60 \mathrm{~s}$. It can be seen on the odd number side of Katolu street even today, where the buildings consist of 4-storey residential buildings with one-room type apartments. These are the so-called hen coops (kuryatnikкурятник from Russian). The types of building layout have been preserved not only in the names of the politicians of the time, but also in the psychoemotional discomfort, accommodating people in a cramped way and making them understand that the time of socialist realism marks an equal distribution of living space for Soviet workers, and that the level of capitalist bourgeois thinking that was characteristic of the dismantled buildings, is unacceptable. This idea was proclaimed by both the constitution of the Soviet state and the Communist Party, which was the "driving, propulsive force" in the development of the new Soviet republic.

These aspects were reflected in the social planning demagoguery of the post-war years in urban planning, in the location of buildings and in the solutions of their façades. Almost 80 years have passed since the beginning of the redevelopment of the city's infrastructure, but it will not be easy to return to the urban environment the semi-historical and socially acceptable aesthetic and functional guidelines [6].
After reading the International Law on the Protection of Monuments (ICOMOS), it is reported that half a century old buildings are gaining the status of a monument. So, the city's post-war buildings are a cultural heritage. This also refers to heritage that marks the intrusion of a foreign political power into the cultural space of another nation. Thus, through synthesis techniques, urban planning must be designed in such a way that the many layers in time and space are functionally and aesthetically acceptable. Gradually, the urban environment will form a structure in which the historical drama of Jelgava buildings can be read [4].

After the war, at the end of the 1940s, in the northern part of Katolu street from St. Yuri's [Sv. Jura] church (architect K. Strandmanis [K. Strandmanis], year 1906) to Liela street (375 m), its location has been changed, sliding the street bed in a slanting manner by $20-40 \mathrm{~m}$. At this stage, the newly built Art Nouveau Latvian Society building was dismantled, with only the roof and windows burned out. Here we can draw parallels with the ambitions of political power, which had been played out already in an analogous style in the city 20 years ago, when the new Latvian government dismantled the "focal point" of the German nobility on the Driksa river bank in the 1920s. So the games of political power in Jelgava continued. Thus, only the church and the adjacent 3-storey tenement house on Katolu street 9 have survived in the northern part of Katolu street, and a small fragment of the 3-storey tenement house at Katolu street 10 on the opposite side. 

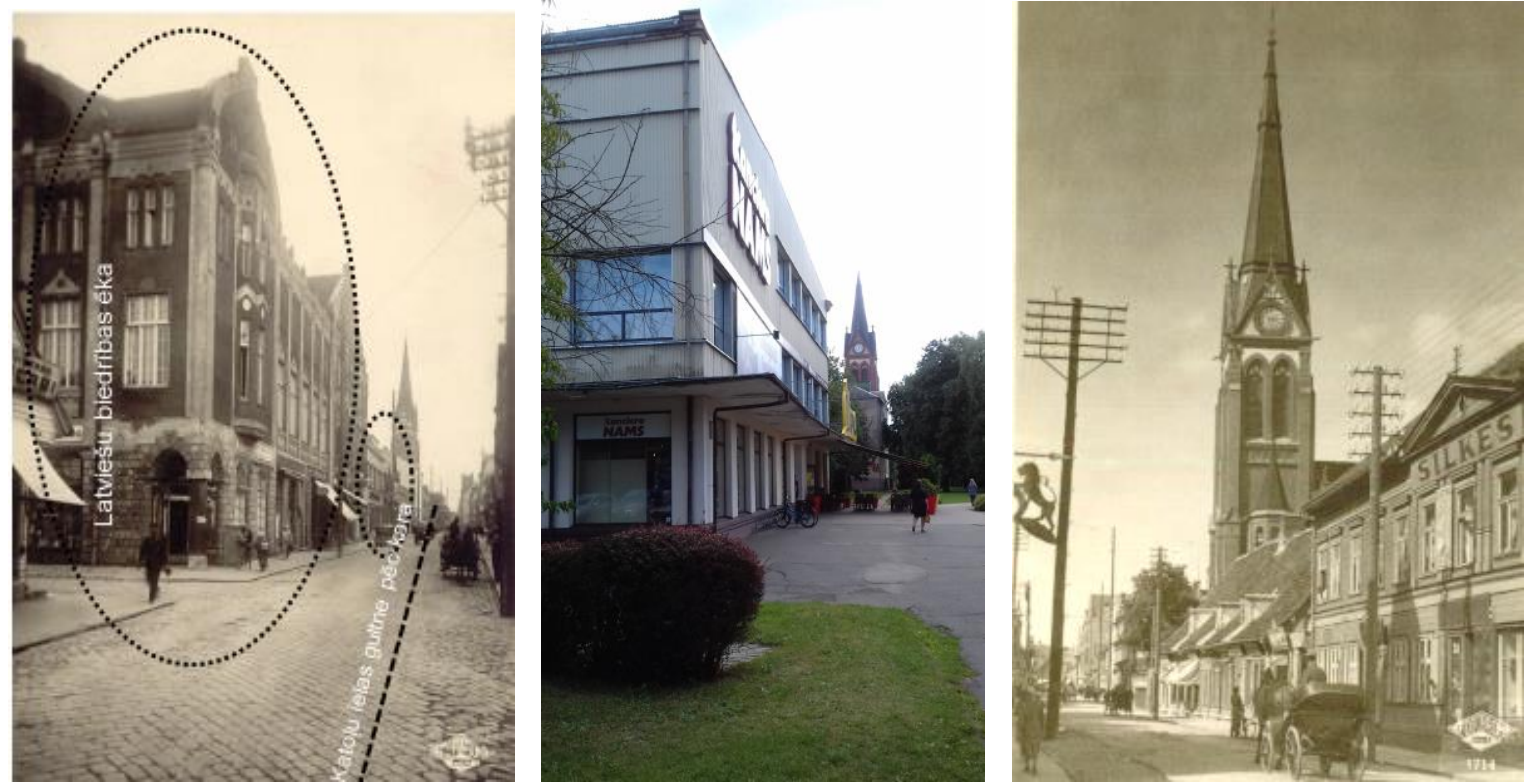

Fig. 5, 6, 7. The northern part of Katolu street, side the odd numbers. Early $20^{\text {th }}$ century [JVM, photo by author, 2020]

A shop was built next to the demolished Latvian Society House in the 1950s, using the dismantled building materials of the Society House.

Like the northern part of the street, the middle section of Katolu street $(220 \mathrm{~m})$ from Raina to S. Edzus (Dika) street has lost all its buildings. Only the tenement house at Katolu street 19 was renovated, for which a top floor and a new roof were built in year 1987. A 5-storey residential building with 8 staircases and a length of 130 meters was built between St. Yuri's [Sv. Jura] church and the mentioned tenement house in the 1960s, vividly symbolizing the tendencies of socialist realism in architecture. The imported volume contradicts the structural "canvas" of the urban space and resembles 5-storey barracks. In addition, the building obscures the main lines of view of the St. Ann's and St. Simon's [Sv. Annas un Sīmaña] church (architect N. Cagins, year 1892), testifying that the political forces of that time were indifferent even to the existence and highlight of the Russian sacred building in the city.

On the opposite side of the mentioned section of the street - a large parking lot - as a message for the destroyed historical buildings along Katolu and Raina streets, which have been accentuating the destroyed historical building area for 76 years.

The southern section of the ruined Katolu street was destroyed in the next decade - during the 1970s, building a grand 5-storey residential quarter instead, and "shortening" the historic street bed by about $260 \mathrm{~m}$. Similar to the middle part of the street, also in this stage it was planned that the new building would obscure the historical dominant - spire of the St. John's [Sv. Jāņa] church. Until the 1970s, Katolu street formed a connection to the Market Square with a highway in the direction of Eleja and Augstkalne, spatially preserving the former Ann's

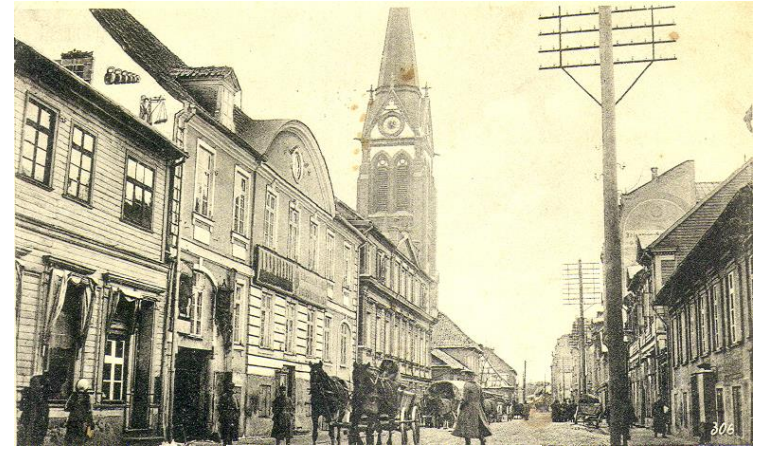

Fig. 8. Katolu street [JVM]

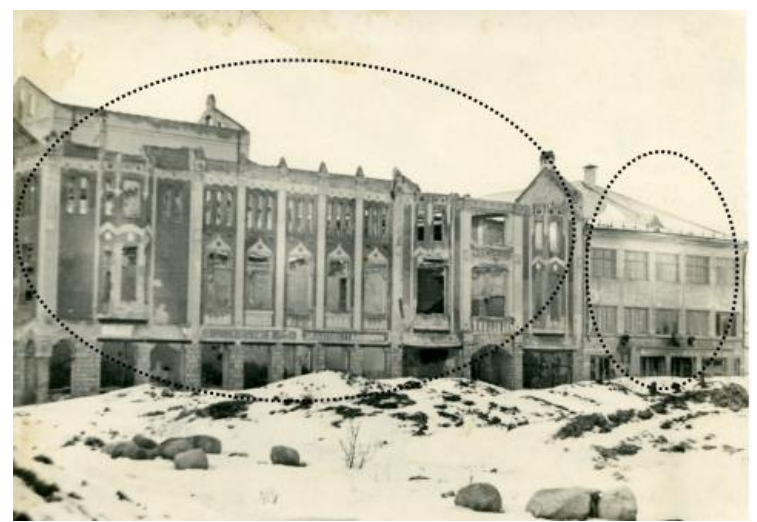

Fig. 9. The northern part of Katolu street [JVM]

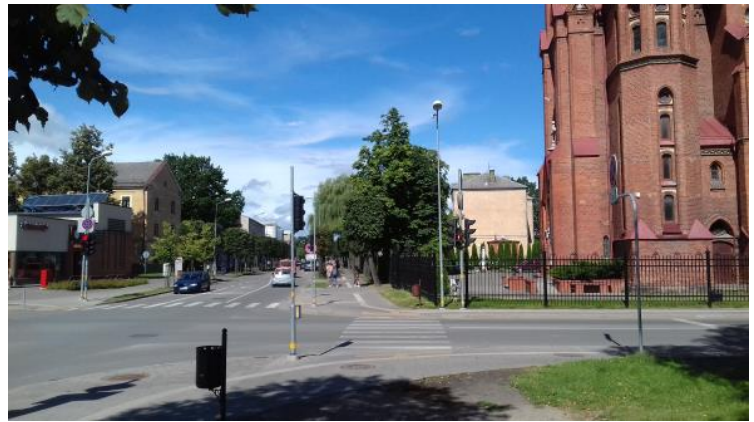

Fig. 10. The northern part of Katolu street [photo by author, 2020] 


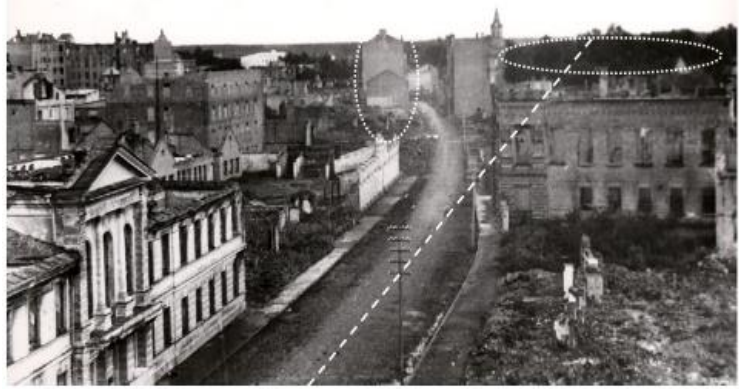

Fig. 11. The middle section of Pasta Street. In the distance is St. John's [Sv. Jāna] church and the cemetery [JVM]

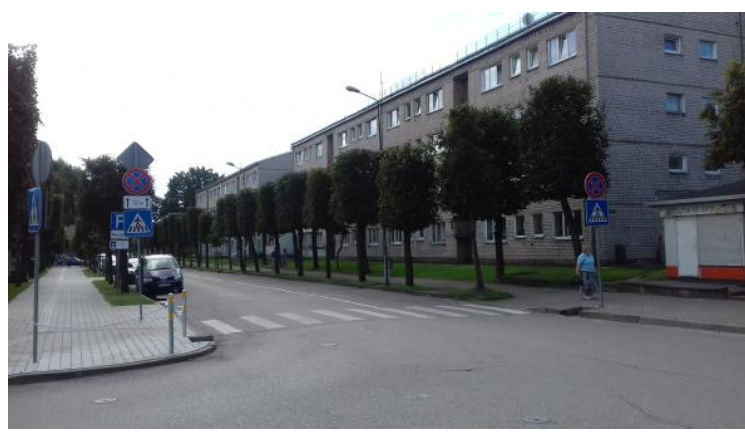

Fig. 12. Khrushchev's residential block houses

(Khrushchevkas) opposite the former Latvian Society House [photo by author, 2020]

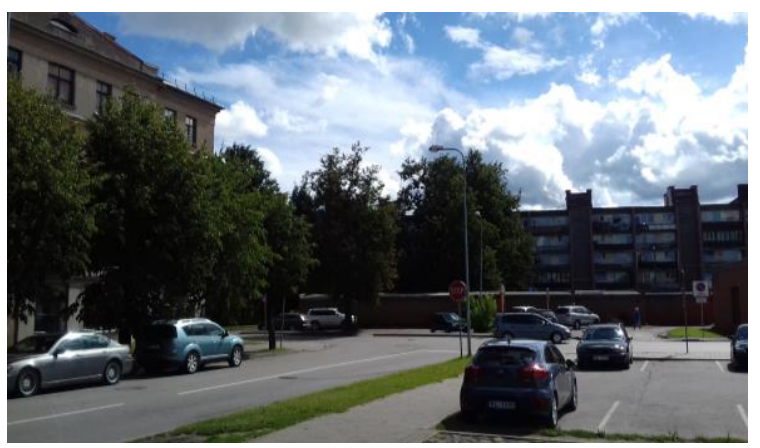

Fig. 13. Intersection of Katolu street and S. Edzus (Dika) street [photo by author, 2020]

[Annas] ports site, which existed until the early 19 th, when the city rampart (wall) was demolished. The southern part of the Katolu street bed $(250 \mathrm{~m})$ has also been removed behind the residential quarter along St. John's [Sv. Jāna] church. In order to eliminate the dominance of the bell tower of St. John's [Sv. Jāna] church, entering from the side of Eleja, two grandiose 4-storey office buildings were built next to the church.

In the western part of the church until the 1950s, there was a historical burial area, which was delimited by a forged metal fence with a gate and an entrance to the church from the side of the cemetery. The entrance to the sacristy of the church was from Katolu street. At present, the church is difficult to see in the urban environment, because it is covered perimeter by both the mentioned buildings and the crowns of giant trees. The western side of the former Katolu street with a sidewalk led tightly along the altar end of the church, the fence connecting to the side walls of the altar. The sidewalk was separated by stone posts from the driveway. Next to the altar the entrance gate to the cemetery, but the entrance to the sacristy of the church was located on the opposite side. The graveyard keeper's house was on the northern side of the burial area next to Jana street. During the 1980s, this was reconstructed. The funeral area today serves as a walking park. Until the war, St. John's [Sv. Jāņa] church was a pronounced vertical dominant in the southern part of Katolu and Pasta streets [2].

\section{Pasta Street}

As mentioned above, Katolu and Pasta streets were historically located close together and until the 1950s ended at the former. Valnu street, close to St. John's [Sv. Jāņa] church, creating a dominant point in the southern urban architectural part of the city, both visually and functionally $[1 ; 10]$.

Before the establishment of a 5-storey residential quarter in the southern part of Katolu street, in the 1950s, an extension of Pasta street through the cemetery of St. John's [Sv. Jān,a] church had already been built in the 1950s, previously dismantling the tombstones which were located there. Thus, the urban structure in the southern part of Katolu street had already been decided sooner and was hidden in the archives under the sign "highly classified".

The northern part of Pasta street from Liela street to Raina street $(350 \mathrm{~m})$ has preserved only the postwar post office building at Raina street 14 . In the post-war years, several Khrushchev's residential block houses (Khrushchevkas) and a bus station building were built during this period, which is encircled by a large area without buildings. It is an area that was lated cleared of debris, and by planting trees here, it created the so-called bus station square. On the opposite side of the street dense construction of 4-storey Khrushchev's residential block houses (Khrushchevkas), creating a continuous courtyard area along the northern part of Katolu street. It was the first realized construction of the standard projects (silicate brick houses with reinforced concrete panel mezzanine floors and flat ruberoid-covered roofs), which occupied an area of 1.2 ha in the central part of the city. Both foreigners from the vast Russia, and military personnel, were accommodated in this territory.

At the beginning of Pasta street, a building was built on Liela street for the needs of the militia (Soviet police), which was adapted to the Executive Committee of the City Workers' Union. Behind it, the aforementioned quarter of Khrushchev's residential block houses (Khrushchevkas) is found, which vividly "decorated" the new political power. In the 1990s, three of the buildings were dismantled, building a giant supermarket instead. 


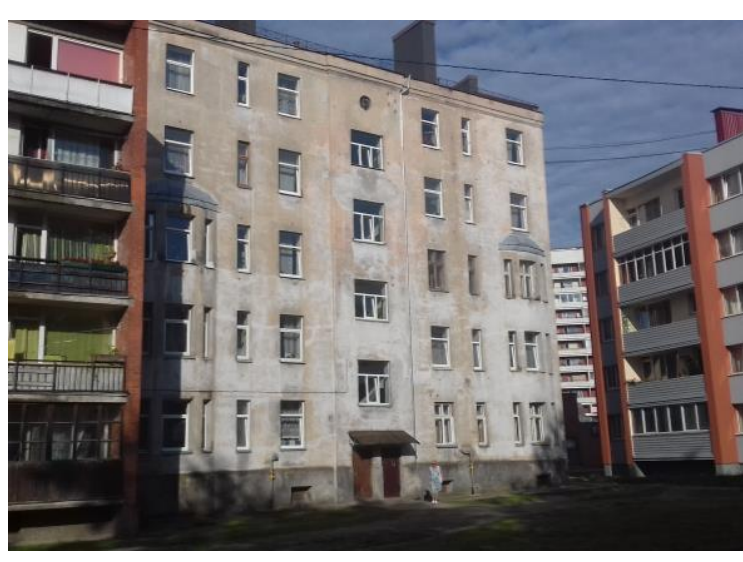

Fig. 14. The middle section of Pasta Street [photo by author, 2020]

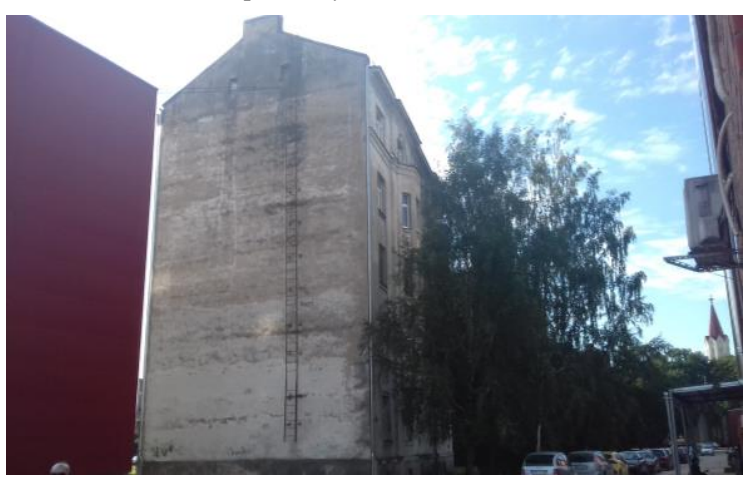

Fig. 15. The middle part of Pasta Street locked-in inside a courtyard [photo by author, 2020]

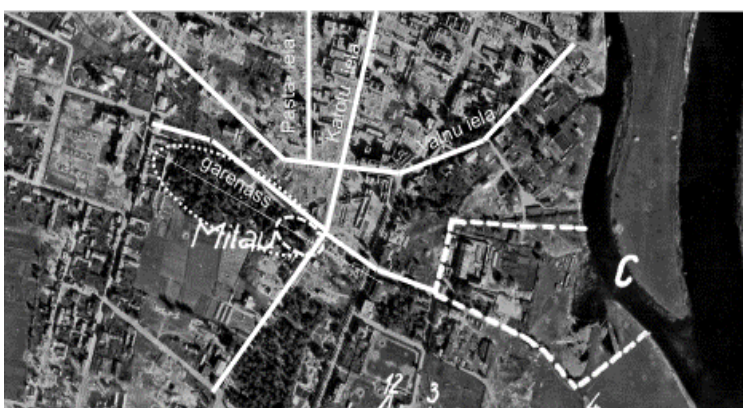

Fig. 16. German army war aviation map. Situation shortly before the bombing of the city in July 1944. Mark on the map

"Mitau C" - territory of the city prison. Jelgava State Art Musuem [JVM, author's sketch]

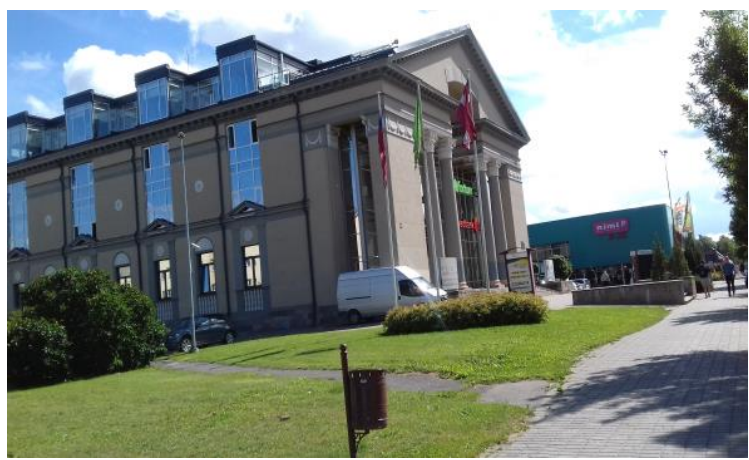

Fig. 17. Former cinema "Zemgale"

(architect J. Jaksins [J. Jakšins], 1955.). Built-in dismantled St. John's cemetery granite blocks, well seen in façade of the building; reconstruction of 2016 [photo by author, 2020]

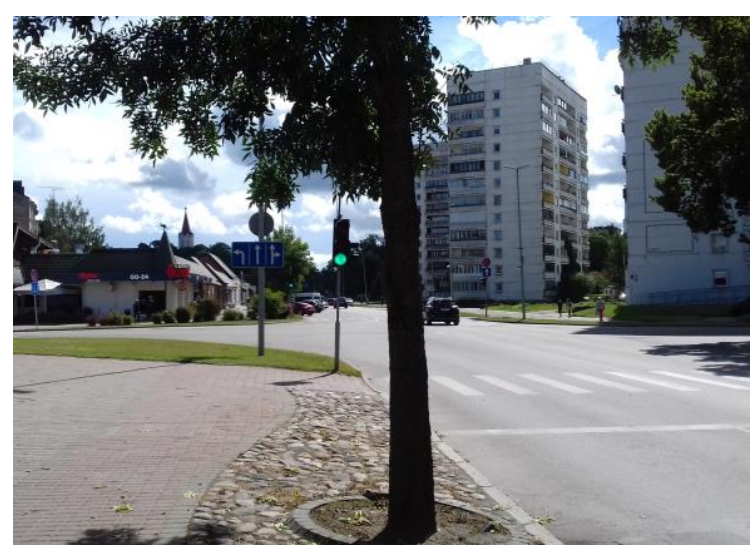

Fig. 18. The middle part of Pasta street [photo by author, 2020]

The middle section of Pasta street from Raina to S. Edzus (Dika) street $(220 \mathrm{~m})$ preserves the former Russian Society House (Pasta street 32), and the scenic environment of the former Pauls Garden (Rainis Park).

On the opposite side of the street-former cinema "Zemgale" (Pasta street 47, architect S. Jaksins [S. Jakšins], 1955), a mighty "Stalinka"type building with massive columns and a triangular pediment. Granite stones were used for the foundations of the building, which were obtained by dismantling the monuments in St. John's [Sv. Jāṇa] church's cemetery. The building is positioned further away from the historical construction line. As an argument, the idea of widening the street was used in order to ensure the passage of the future would-be traffic.

Nearby, a large parking lot is located - a place of levelled war ruins of old buildings. A giant square, which is foreign to the urban structure and clearly indicates a disrupted structure of the urban space. The wooden elements of the demolished and burnt buildings were used for heating the stoves in wintertime, but the dismantled bricks were adapted for the construction of new masonry buildings. At this stage of the street, until the 1950s, clock-tower spire of the St. John's [Sv. Jān,a] church could be seen.

In the southern part of Pasta street, in the section from S. Edzus (Dika) street to Jana street $(240 \mathrm{~m}$ ), only the Art Nouveau 5-storey tenement house of Pasta Street 53 has survived. The further section of Pasta street after Jana street leads through the destroyed cemetery $(97 \mathrm{~m})$ in the general direction of Lithuania.

The resistance movement in the city ended with repression and manipulation of public opinion, which was practised by the occupying power until the 1980s. The resistance was based on the process of destroying the resting places and monuments of families and popular people, which began in the 1950s. By dismantling of the southern part of 


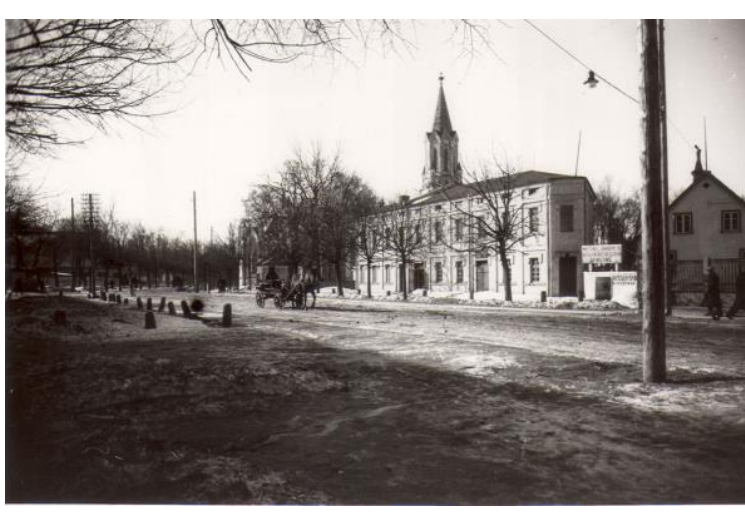

Fig. 19. The lost southern part of Katolu street at the former Ann's [Annas] gate (intersection of Jana and Katolu streets), 1930s [JVM]

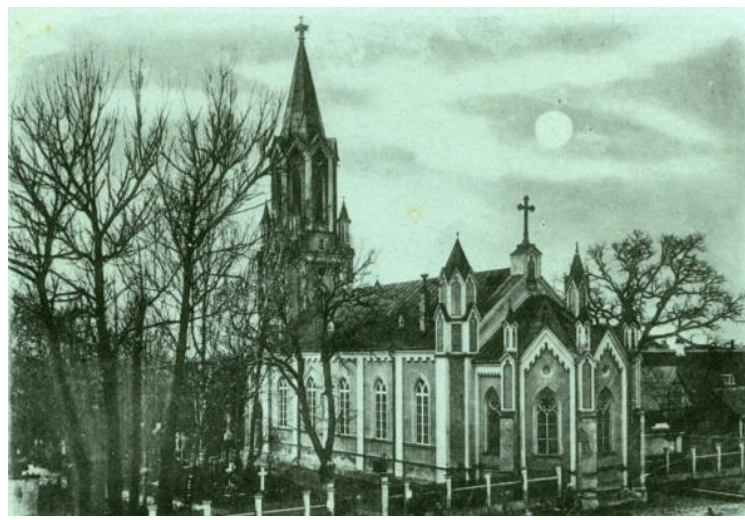

Fig. 20. Bell-tower of St. John's [Sv. Jāna] church [JVM]

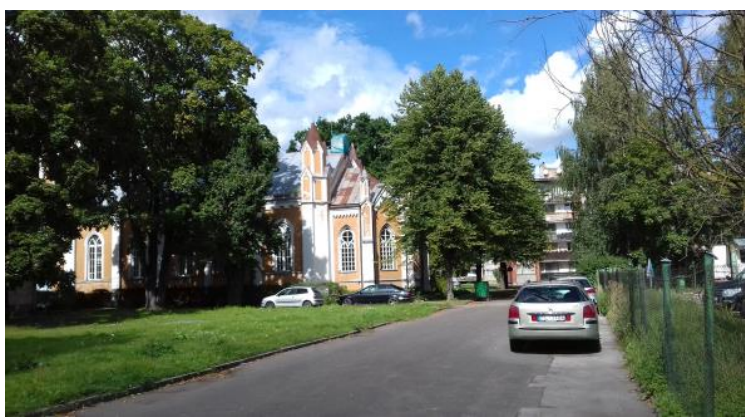

Fig. 21. Bell-tower of St. John's [Sv. Jān,a] church [photo by author, 2020]

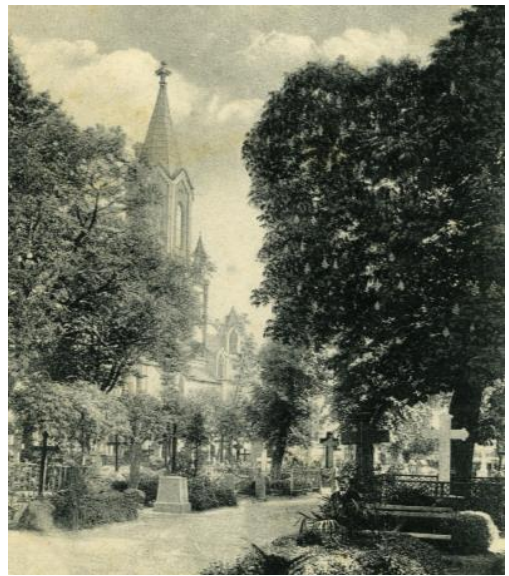

Fig. 22. Bell-tower of St. John's [Sv. Jāna] church from the side of the cemetery in 1930s [JVM]

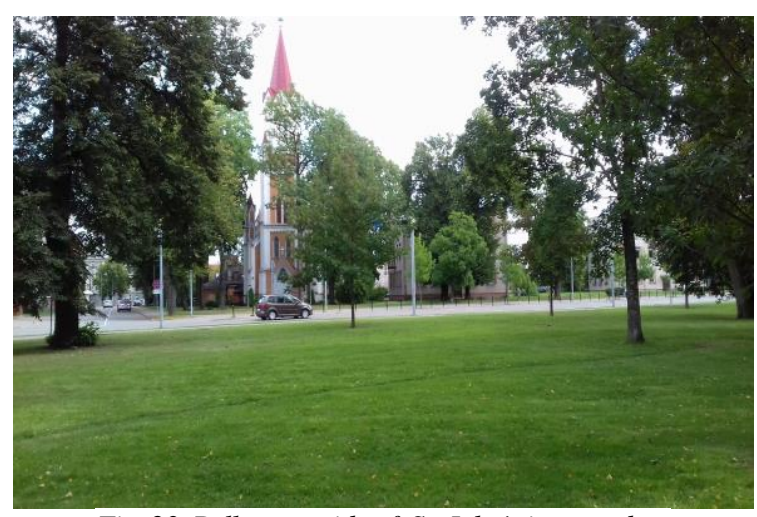

Fig. 23. Bell-tower side of St. John's in nowadays [photo by author, 2020]

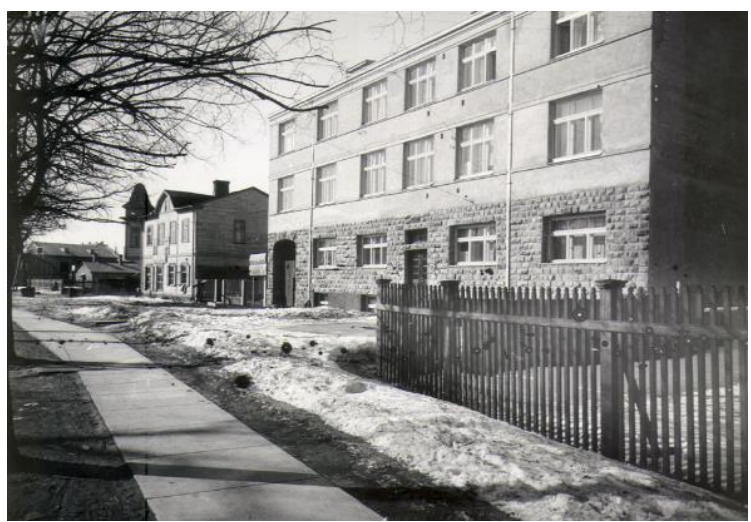

Fig. 24. Historic buildings at the intersection of Pasta-Stacijas street, 1930s [JVM]

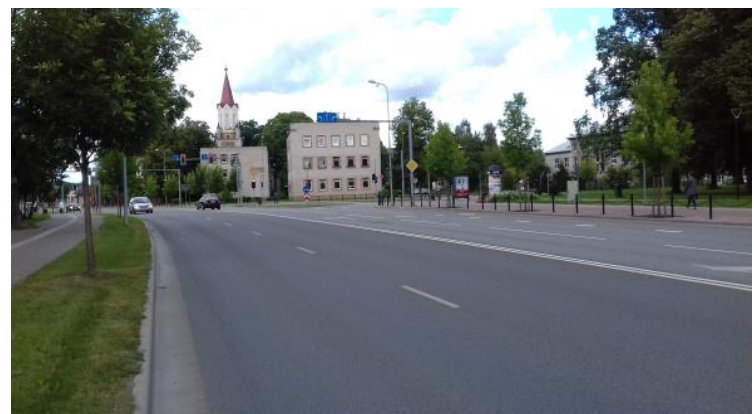

Fig. 25. View to the church from Pasta street [photo by author, 2020]

Katolu street, the overall structure of the urban planning was completely changed [3; 4].

Pasta street in the southern part of the cemetery was connected to the former Lietuvas street, where a 2-storey residential building with a corner tower (Stacijas street 2) has been preserved at the intersection with Stacijas street.

During the 1980s, on the side of even numbers on Pasta street, three 12-storey buildings were placed in the length of $125 \mathrm{~m}$ opposite the former cinema "Zemgale", which visually rendered the bell tower of the adjacent St. John's [Sv. Jāna] church even more diminutive. In its turn, the 5-storey Art Nouveau tenement house at Pasta street 53 was successfully hidden behind the $230 \mathrm{~m}$ long building line of commercial buildings and the 5-storey 
standard residential buildings. These building areas were acquired for use after the debris was removed [7].

\section{Conclusions}

Examining only two of the many historical streets in the southern part of the old Jelgava, and using the comparative method, it can be seen that both streets still have a lot of research to be done in order to find out the exact location of the burned buildings. The study needs to be complemented by information that can be obtained with the help of modern technology, using scanning and photo fixation, and obtaining the locations of historical bases and foundations. The third dimension, or the heights of the buildings, can be read from the very large archive photo collection.

It is impossible to regain the size and volumetric appearance of the completely burned city, but the search for synthesis in the architectural stylistics and functional sense of modern and historical buildings exists. This is especially true of those places where the so-called gaps or undeveloped areas have been retained in street settlements and structures. Katolu and Pasta streets have become very much planted with greeneries in the post-war years.
Historically, they were not characterized by substantial tree plantations. This has been facilitated by the creation of areas which were freed from the debris.

The study proves that the nature of urban planning, which developed in the post-war years, is a continuation of the building's contribution to the city's cultural heritage, which in a balanced form and functionality should be transferred to the 21 st century and future urban infrastructure, using the latest technologies. The Soviet rule in the period from 1950s to 1980s brought a new scale and understanding of the greatness of Soviet cities, eliminating sentiment about values of cultural heritage. A foreign political position dismantled heritage values or created a disguised structure, as the examples discussed above clearly depict.

The research material is important for promotion of the city's tourism infrastructure, which can be supplemented with information stands, cultural events, etc. The nuances of the city's historical planning and architectural stylistics, and the layering of post-war building trends, can serve well for the development of new infrastructure and business in the city.

\section{References}

1. Briṇkis J., Buka, O. Pilsētu un lauku apdzīvoto vietu kompleksu arhitektoniski telpiskā plānošana. 2006., 232. lpp.

2. Deksne, I. Jelgavas parki stāsta. 2020, Jelgavas pilsētas Dome, 207. lpp.

3. Grosmane, E. Senā Jelgava. 2010., Neputns, 335. lpp.

4. ICOMOS. ANO Generālā konference. Preambula par 2011. g. 10. nov. vēsturisko pilsētu ainavu.

5. Jelgavas albums. JVMM, Jelgavas pilsētas pašvaldība, 2017, 335. lpp.

6. Krastiňš, J., Dripe, J, Strautmanis, I. Latvijas arhitektūra. 1998., Baltika, 311. lpp.

7. Mintaurs, M. Arhitektūras mantojuma aizsardzības vēsture Latvijāa. 2016., Neputns, Rīga, 252. lpp.

8. Schlau, K. O. Mitau im 19. Jahrhundert. Verlag Hirschheydt,1995,

9. Tomašūns, A. Mana Jelgava. Jelgavas pilsētas pašvaldība, 2015.

10. Ziemelniece, A., İle, U. Search for the synthesis of cultural heritage and modern architecture in multistory residential areas: example of Jelgava / Mitau. Symposium. WMCAUS. 2020, Praha.

11. Ziemelniece, A. Transformation of the landscape space in the post war years. Jelgava example.

AUTHOR:

Aija Ziemeḷniece, Dr.arch., Professor at the Faculty of Environment and Civil Engineering, Department of Landscape Architecture and Planning of the Latvia University of Life Sciences and Technologies, 22 Liela iela, Jelgava, Latvia, LV-3001. E-mail: aija@k-projekts.lv

Kopsavilkums. Pētījums par Jelgavas pilsētu pierāda, ka pilsētplānojuma raksturs, kas veidojies pēckara gados, ir apbūves pienesuma turpinājums pilsētas kultūras mantojumam, kas sabalansētā formveidē un funkcionalitātē jāpārnes tālāk 21. gs. pilsētas infrastruktūrā, ņemot talkā jaunākās tehnologijijas. Padomju vara 20.gs.50. -80.gados ienesa jaunu mērogu un izpratni par padomju pilsētu varenību, likvidējot sentimentu par kultūras mantojuma vērtībām. Svešādā politiskā nostāja mantojuma vērtības demontēja vai arī veidoja maskējošu apbūvi, ko spilgti pierāda iepriekš aplūkotie piemēri.

Pētījuma materiāls ir svarīgs pilsētas tūrisma infrastruktūras veicināšanai, kas ir papildināms ar informatīvajiem stendiem, kultūras pasākumiem utt. Pilsētas vēsturiskā plānojuma un apbūves arhitektoniskās stilistikas nianses, un pēckaru gadu apbūves tendenču uzslāņojums var labi kalpot jaunas infrastruktūras un uznēēējdarbības attīstīšanai pilsētā. 